\title{
The Disruptive Potential Of Robo- Advisory On The Wealth Management Business Model Of Banks
}

\author{
Cam-Duc $\mathrm{Au}^{1}$ and Alexander Zureck ${ }^{2, *}$ \\ ${ }^{1}$ FOM University of Applied Sciences E-mail: \\ cam_duc_au@gmx.de \\ ${ }^{2}$ FOM University of Applied Sciences/Masaryk University isf Institute for \\ Strategic Finance/Faculty of Economics and Administration E-mail: \\ alexander.zureck@fom.de*Corresponding author
}

\begin{abstract}
We investigate the disruption potential of robo-advice on the wealth management market in Germany. The special focus on the German market intends to close the gap of scarcely existing literature for this target country. Our qualitative research approach consists of 13 conducted expert interviews with top-management representatives from the financial industry. The interview transcripts underwent a structured content analysis based on inductive and deductive categories resulting from a performed literaturereview. The key findings indicate, that there are four major obstacles avoiding significant disruption in personal wealth management: (1) pending performance proof in market drawdowns, (2) misleading price-performance-ratio, (3) limitations in the affluent business and (4) the existence of the scaling-strategyparadox. Our overall conclusion stresses the fact, that robo-advice is relevant for German investors and thus for banks to implement in their service offering. Although the digital service misses a long-standing track record and even may not be as costefficient as suggested, it already demonstrates disruption in the retail business. However, robo-advisors are technically not ready yet to meet investor needs of high net-worth individuals, which may be decisive due to an upcoming market consolidation. Scaling effects are difficult to achieve without collecting high investment volumes from the affluent business segment. Hence, current robo-advicestrategies on market are paradox due to their technical capabilities and strategic orientation on the retail market.
\end{abstract}

Keywords: automated investment advice; digital asset management; digitization; fintechs; robo-advice 


\section{Introduction}

The traditional banking industry faces various challenges. Banking clients today are demanding new digital and innovative financial solutions in order to simplify their financial operations. This demand is still insufficiently covered by the traditional market players. Additionally, the loyalty is decreasing constantly, and customers have a willingness to change their financial partners.

The current example of the German FinTech Wirecard AG demonstrates the rise and meaning of innovative and IT-driven financial companies. Wirecard states the first FinTech to move up to the DAX 30, thereby replacing and sending the index founding member Commerzbank AG to the MDAX. This example underlines the potential and threat of aspiring FinTechs to challenge old-established bank companies for market shares (Dörner et al., 2018).

Referring to the CFA Institute, a conducted survey among charterholders determines robo-advisory - besides blockchain, crowdfunding and other digital banking technologies - as the most influential trend in financial services for the upcoming years. Innovative FinTech companies such as Scalable Capital, Whitebox, Quirion, or Growney are already successful on the German market (CFA Institute, 2016).

Since robo-advisory still represents a young technology with a historical beginning in 2008, there are scarcely investigations on the substitution effect on the wealth management business of banks (Singh \& Kaur, 2017). The primary literature, in fact, emphasizes possible USPs and the future technological potential behind the immature software. Consequentially, the lack of qualitative investigation on the disruptive force results in an insufficient scientific reflection on the digital advisory software. Furthermore, the targeted banks may not be able to fully assess the potential threat in order to conduct measures for business stability (Beyer, 2017, Huxley \& Kim, 2016, Tertilt \& Scholz, 2018).

The paper makes the possible impact of robo-advisory on the wealth management business models of banks as subject of discussion. By pursuing a qualitative research approach, experts from traditional banks, robo-advisors and a management consultancy serve as information sources.

\section{Methodology}

The given work deals with the disruptive potential of robo-advice on the wealth management business of banks in Germany. A conducted literature-review proves that there is no far-reaching literature yet. Hence, the qualitative research method by means of expert interviews is suitable to gain new insights on the impact of roboadvice. It is the aim to identify hypotheses that can be verified in future quantitative research. The selection of experts provides a cross-section of the German banking industry with their direct or indirect connection towards robo-advice. Table 1 shows information about the participating companies and the interview data. 


\begin{tabular}{|c|c|c|c|c|c|}
\hline \multicolumn{6}{|c|}{ Figure 1: Overview of Interview Experts } \\
\hline Interview & Company & Date & Form & $\begin{array}{l}\text { Word } \\
\text { Count }\end{array}$ & Duration \\
\hline Expert 1 & Comdirect AG & $\begin{array}{c}\text { 2018-06-21 } \\
\text { 15:00 CET }\end{array}$ & Personal & 1.854 & 31 Minutes \\
\hline Expert 2 & $\begin{array}{c}\text { Commerzbank } \\
\text { AG }\end{array}$ & $\begin{array}{c}\text { 2018-06-29 } \\
\text { 10:30 CET }\end{array}$ & Personal & 1.558 & 21 Minutes \\
\hline Expert 3 & $\begin{array}{c}\text { Deutsche } \\
\text { Apotheker- und } \\
\text { Ärzte Bank eG }\end{array}$ & $\begin{array}{c}\text { 2018-06-29 } \\
\text { 16:00 CET }\end{array}$ & Personal & 1.633 & 19 Minutes \\
\hline Expert $4 \& 5$ & $\begin{array}{c}\text { Stadtsparkasse } \\
\text { Düsseldorf }\end{array}$ & $\begin{array}{c}\text { 2018-07-06 } \\
\text { 13:00 CET }\end{array}$ & $\begin{array}{l}\text { Personal } \\
\text { (Double } \\
\text { Interview) }\end{array}$ & 2.281 & 74 Minutes \\
\hline Expert 6 & $\begin{array}{c}\text { Deutsche Bank } \\
\text { AG }\end{array}$ & $\begin{array}{c}\text { 2018-07-11 } \\
12: 30 \text { CET }\end{array}$ & Personal & 2.299 & 30 Minutes \\
\hline Expert 7 & $\begin{array}{l}\text { HQ Trust } \\
\text { GmbH }\end{array}$ & $\begin{array}{l}\text { 2018-07-13 } \\
\text { 11:00 CET }\end{array}$ & Personal & 2.019 & 31 Minutes \\
\hline Expert 8 & $\begin{array}{c}\text { National-Bank } \\
\text { AG }\end{array}$ & $\begin{array}{c}2018-07-13 \\
13: 30 \text { CET }\end{array}$ & Personal & 1.876 & 50 Minutes \\
\hline Expert 9 & $\begin{array}{c}\text { ODDO BHF } \\
\text { AG }\end{array}$ & $\begin{array}{c}\text { 2018-07-30 } \\
\text { 10:00 CET }\end{array}$ & Personal & 2.707 & 49 Minutes \\
\hline Expert 10 & quirion $\mathrm{AG}$ & $\begin{array}{c}\text { 2018-07-31 } \\
14: 00 \text { CEZ }\end{array}$ & $\begin{array}{c}\text { By } \\
\text { telephone }\end{array}$ & 2.063 & 34 Minutes \\
\hline Expert 11 & $\begin{array}{l}\text { Rothschild } \\
\text { Vermögensver } \\
\text { waltungs- } \\
\text { GmbH }\end{array}$ & $\begin{array}{c}\text { 2018-08-07 } \\
\text { 11:00 CET }\end{array}$ & Personal & 2.400 & 56 Minutes \\
\hline Expert 12 & Anonymous & $\begin{array}{l}\text { 2018-08-01 } \\
\text { 17:00 CET }\end{array}$ & Personal & 2.207 & 31 Minutes \\
\hline Expert 13 & micobo GmbH & $\begin{array}{c}\text { 2018-08-29 } \\
\text { 19:30 CET }\end{array}$ & Personal & 3.492 & 49 Minutes \\
\hline Expert 14 & Prospery GmbH & $\begin{array}{l}\text { 2018-08-09 } \\
\text { 11:00 CET }\end{array}$ & Personal & 1.703 & 22 Minutes \\
\hline & & & & $\begin{array}{c}\text { Total of: } \\
28.092 \\
\text { words }\end{array}$ & $\begin{array}{c}\text { Total of: } \\
496 \\
\text { Minutes }\end{array}$ \\
\hline
\end{tabular}

Source: own depiction

By way of example, Commerzbank $A G$ and Deutsche Bank $A G$ are the two biggest German banks, thereby representing robo-advisory endeavors of traditional financial institutes. The selection of Deutsche Apotheker- und Ärztebank eG and National-Bank $A G$ - as medium-sized and specialized commercial banks - completes this consideration. According to Krahnhof and Zureck, especially medium-sized German banks are facing difficult challenges of digitizitation to compete with innovative competitors or cope with regulatory requirements (Krahnhof \& Zureck, 2018). For purposes of comparison, two traditional asset managers (Rothschild Vermögensverwaltungs-GmbH, ODDO 
BHF $A G$ ) and one digital asset manager (quirion AG, whose parent company Quirin Privatbank $A G$ is the only German bank providing investment advice on a fee basis) were consulted in order to receive information on their robo-advisory opinions and plans. The choice for the family office $H Q$ Trust $G m b H$ and the management firm Micobo $\mathrm{GmbH}$ serves as additional sources to gain a more diversified view on the research topic.

The utilized interview guideline is based on the conducted literature-review and states the framework to extract the expert knowledge. The content structure can be divided into the parts of introduction, general questions, main questions, final question, and interview termination. The complete interview guideline was available for preparatory purposes before the meeting. Hence, it was sent to all experts beforehand via mail.

The 13 interviews are to be analyzed, thereby being transcribed and anonymised. Afterwards, the gained information underwent a systematic analysis approach. The structured qualitative content evaluation according to Mayring assists in organizing and compressing unstructured mass information in order to gain the key messages. In doing so, mass information can be sorted by topics, contents, and aspects to find answers. This takes places in a highly scientific and structured manner to pay justice to the obtained insider-information of the experts interviewed. A developed category system states the base for the coding process (Mayring, 2002).

\section{Results}

\subsection{Performances Remain to be Proven in Market Drawdowns}

The results from the literature-review as well as the expert interviews conform with the fact, that there is a "raison d'être" for the robo-advice-market (Expert 1, Expert 3, Expert 10). The banking clients are demanding innovative and digital solutions for their financial matters (Expert 4). This confirms the existing trend of investors to take advantage of robotic advice because it pays justice to the demand. Besides, the American market as benchmark for robo-advice has already proven, that investors tend to utilize this investment alternative. The total estimated number of USroboinvestments amount 16 billion Euros, whereas the German market is believed to reach a number up to 1.5 billion Euros (Freiberger, 2018).

Focused on the German investment market, robo-advice still experiences significant positive developments in terms of retrieved investment volumes. It still represents only a small fraction of the total wealth management market (Expert 2). One reason for the small market share lies in the novelty of this service. Despite decent investment performances and good results from independent quality inspections, the interview findings emphasize, that robo-advice still have to prove its resilience in negative market phases. Huxley and Kim emphasize, that long-term track records are still missing for fair evaluations (Huxley \& Kim, 2016). Furthermore, the literature is still debating which investment approach is superior in terms of investment performance. There are manifold investment strategies and models to follow. For instance, the study from Faber deals with the quantitative approach to tactical asset allocation and the chance for investors to increase risk-adjusted returns (Faber, 2018). In contrast, Chen et al. 
researches dynamic asset allocations with ambiguous return predictability to find the right choice between two possible stock models (Chen et al., 2011). The examples only constitute a small fraction of investment approaches, which wealth managers are facing. The industry itself causes the great hype about robo-advice but still did not have the chance to deliver prove (Stiftung Warentest, 2018).

However, the remaining prove is not necessarily based on the unwillingness of roboadvisors and their algorithmic investment systems to deliver. It rather can be referred to the beneficial introduction date of robotic advice. The financial market developments were in favor of the digital advisory service, thereby fostering a positive image of a successful investment system. Furthermore, there were no significant crises, which impact can be compared, for instance, to the Financial Crisis in 2007 (Expert 4 \& 5).

"It will be interesting to see negative markets. Then it requires quality in the service. We currently have markets, which are in favor of robo-advisors. If you cannot stand up in this beneficial environment, then you do not belong on the market."

(Expert 4 \& 5)

Referring to the corresponding working hypothesis in Table 1, it cannot be confirmed, that digital customer profilings offer the same quality as its personal pendant. In fact, it constitutes an even worse process when compared to personal services. A human advisor is more flexible in terms of questioning investor details and dominates in the field of knowledge assessment as well as transfer (Expert 3). A human being is able to consider the surrounding and the background of his counterpart. By this way, social, religious, and other aspects can be respected by an individual but not by a digital advisor in the whole (Zureck et al., 2018, Zureck \& Jäger, 2018)Source).

Table 1: Working Hypothesis 1-Digital Customer Profiling

\begin{tabular}{|c|c|}
\hline $\begin{array}{c}\text { Working } \\
\text { Hypothesis } \\
1\end{array}$ & $\begin{array}{c}\text { If customers use the digital customer profiling process of robo-advisory services, } \\
\text { then they will experience the same quality as in personal wealth management } \\
\text { services. }\end{array}$ \\
\hline
\end{tabular}

Source: own depiction

In Summary, robo-advice in its current stadium is regarded as an important client offer. Nonetheless, it still possesses limitations regarding the integration of emotional factors and the comprehension of an investor's subjective investment perception. Furthermore, many robo-advisors still have to prove their sole quantitative investment models in critical market phases. In the end, it is a worth investing business field to not miss the logical and consequential evolution of wealth management (Expert 6, Expert 13).

\subsection{Misleading Perceptions on Digital Price-Performance-Ratio}

The study results of Jung et al. show that customers are still highly focused on costs and robo-advisors have to provide appropriate digital transparency (Jung et al., 2017). The business model of robo-advisors mainly makes use of passive funds in order to build a portfolio. Passive funds or ETFs show low costs due to its nature of displaying a certain reference or index (Expert 1, Khentov et al., 2016, Meinert, 2017). Therein, it is not required to perform regular transactions because references do not often have 
changes. This low pricing shall be passed on to the investors of robo-advisors. They advertise with lower pricings, thereby suggesting a fair investment offer (Expert 4, Expert 10). By now, there are also robo-advisors, which offer active funds or the integration of single stock and sector selections. The roboadvisor Solidvest was independently mentioned by three interview experts as role model to offer adequate individuality and diversity in its portfolios (Expert 2, Expert 6, Expert 9).

Before referring to the findings on this field, it is important to distinguish between the primarily advisory and fund costs. Clarfeld describes the pricing as "beyond a fee listed within the fine print" (Clarfeld, 2017). While advisory costs are regularly stable, fund costs can vary from the investments within the portfolio. Passive investments have lower fund costs, whereas active funds pose the opposite. The latter uses active management as targeted strategy to outperform a benchmark. As a consequence, fund costs are variable and need to find corresponding consideration to the advisory costs. Independent quality testers, such as Stiftung Warentest, control advisory costs in addition with own calculations on the additional fund costs of the examined portfolio. Yet, other testers focus solely on the advisory costs. Both different approaches often lead to different test results. Interested clients have to consider this differentiation for an investment decision (Stiftung Warentest, 2018).

One finding resulting from the interviews shows, that there is often a misleading perception on the pricing of robo-advice services. Bank representatives counter with the argument, that their pricing is indeed able to compete with robo-advisors. The representative of the $O d d o B H F$ Bank $A G$ also sees his company in a good position to compete with robo-advisors and their pricing strategy:

"The pricing of a balanced mandate with an asset under management of approximately one million Euro lies between 1-1,20\% per year. If you take a look in our portfolios, then you will see an allocation of over $95 \%$ of individual stocks."

(Expert 2)

According to the research findings of Fein, the American market for robo-advice is facing an identical "misleading if not completely false" perception on pricing (Fein, 2015). The results of the interview with the representative of quirion $A G$ demonstrates one exemplary robo-advisor to have a lower pricing than its bank competitors. The pricing statement matches the results from Stiftung Warentest (Stiftung Warentest, 2018). When asking quirion about their pricing success, the expert explains the reasons behind as follows:

"We have low costs because we have a private bank behind us. We do not have to build new banking systems. The infrastructure is already given. We can keep our backend and personnel costs low because we are a scion of a private bank and we already have the knowledge about business processes and regulatory requirements to avoid double personnel functions."

(Expert 10) 
Source: own depiction

Table 2 illustrates the working hypothesis, that investors will experience a better price-performance-ratio, if the decision falls for the digital provider. This hypothesis cannot be confirmed due to the two findings mentioned. Bank pricings are indeed competitive, whereas some robo-advisors are even more expensive. In addition, personal advisory always includes the analysis and explanation of the total financial situation and does not request an extra charge (Expert 5, Expert 8, Expert 9

To sum up, the price-performance-ratio is misleading because bank pricings are in fact competitive and they offer holistic financial advice in further spheres of asset management, which does not find consideration at all in the price comparisons in literature and independent quality tests (Expert 12, Stiftung Warentest, 2018).

\subsection{Limited Disruption in the Affluent Business}

All interviewed experts agree, that robo-advisory constitutes an elementary component for banks. In their joint opinion, it is going to disrupt the retail business of banks. Retail clients have a less complex financial situation and thus require less individual advisory services. Faloon and Scherer argue that most of the robo-advisors still provide generic and thus insufficient advice (Faloon \& Scherer, 2017). The necessity of human advice becomes visible, when it comes to complex financial situations (Expert 6, Expert 7).

Since the nature of wealth management service targets high-volume customers, the client base of HNWI show complex financial asset structures. In contrast to retail clients, HNWI demand customized and individual financial advisory services. Not only the bank experts, but also the representatives of robo-advisors confirm this factor as a significant weakness of digital wealth management. Quirion agrees on the limitation in regard to individual requirements, but simultaneously state, that HNWI are welcome and that they already make use of the service. The HNWI business is mainly covered by the Quirin Privatbank (Expert 10).

"We welcome wealthy clients in our digital portfolio solution. The strategic difference is, that our private bank targets the complex business with HNWI, whereas we cover the demand in the retail business market."

(Expert 10)

Most of the existing robo-advisors on the German market offer either active or passive portfolio strategies. Investors can choose between a determined set of predefined asset allocations (Expert 8). The possession of an USP is relevant for the upcoming consolidation on the robo-advisory market. Introducing a differentiation strategy in the product offering is the next big step:

"There are over 30 providers on the German robo-advisory market. What can I do better? It is not all about service, but also about the product. LIQID has a great USP 
because they have investments in private equity. The next big step is a differentiation in the product offering."

(Expert 13)

The hypothesis in Table 3 cannot be confirmed. Robo-advisors such as quirion, Prospery or Cominvest thus offer additional human advisory against a fee to compensate this gap. In these exemplary hybrid cases, emotional decision-making factors are integrated in the digital advisory process. The majority of robo-advisors in Germany do not fulfil this criterion and thus cannot confirm the given working hypothesis.

Table 3: Working Hypothesis 3 - Emotional Decision-Making Factors

\begin{tabular}{|c|c|}
\hline $\begin{array}{c}\text { Working } \\
\text { Hypothesis } \\
3\end{array}$ & $\begin{array}{c}\text { If customers use robo-advice, then their emotional decision-making factors will } \\
\text { be integrated within the digital advisory process. }\end{array}$ \\
\hline Source: own depiction
\end{tabular}

Summarizing, the interview findings show unanimous agreement on the disruptive potential on the retail business of banks. The segment with HNWI remains stable due to the existing limitations in the digital offering. A possible future advancement is the offer of a hybrid robo-solution in combination with optional human consultancy. Offering both possibilities provides a convenient service for all investor types. The research findings of van Thiel and van Raaij indicate, that "convenience appears to be the dominant factor" when to observe robo-advice from an investor perspective (van Thiel \& van Raaij, 2017). In doing so, robo-advisors can reach an equivalent service quality to challenge the bank business with HNWI in a disruptive manner.

\subsection{The Scaling-Strategy-Paradox}

The scientific analysis of the interview results revealed a major mistake regarding most of the robo-advisor's business strategies. The findings so far emphasize the suitability of digital wealth management for the standard demands of retail clients. Hence, the experts agree on the disruptive force on the retail business of traditional banks. This fact stands in alignment with the robo-advisor's strategic direction of targeting the retail investor market (Expert 8, Expert 10).

Robo advisors often stress the point, that they want to address the broad group of clients, which do not have profound experience in asset management. The digital process offers a lean process as well as good visualizations to make investments less complicated and more precise (van Raaij, 2017). In doing so, the companies can attract new customer groups, which are not covered by traditional banks and their offerings yet. Against this background, the robo-strategy offers sophisticated wealth management for small investment volumes. The targeted retail investors can participate with little lump sums or savings plans.

However, the following six facts are questioning the robo-advisor's retail strategy and its sustainable dimension to remain on market in the long run:

1. The German robo-market is in a current state of consolidation (Expert 13)

2. Reaching a critical mass is required for scaling effects (Expert 13) 
3. Scaling effects require high investment volumes of HNWI (Expert 13)

4. Majority of robo-offerings do not yet meet the demands of HNWI (Expert 1)

5. "Achieving security investments is still pioneering work for the banks." (Expert 8)

The majority of the existing literature base of robo-advice focuses on the US or Asian market, which cannot be compared with the German investment market. The German investment mentality is still characterized by a low acceptance towards security investments. The interview experts indicate, that the age structure of their clients which are interested in capital market investments - is 40 and above. Hence, the idea of robo-advisors to gain new and young customers cannot yet be regarded as true. German shareholders are still coming from the same existing generation (Expert 1, Expert 2, Fey \& Hohlmeier, 2018, Zureck et al., 2018).

Based on the presented facts and expert statements, most businesses of robo-advisors face a scaling-strategic-paradox. The HNWI business is fundamental to gain a critical mass and to compete on market. HNWIs are also among younger generations and needed to be addressed due to the great business potential. Freiberger expects a consolidation on the German market and robo-advisors are advised to win as much market shares as possible to survive (Freiberger, 2018). The intention of collecting broad assets on the mass market still constitutes difficult business in Germany (Expert 8, Expert 13).

Table 4: Working Hypothesis 4 - Disruptive Force on Personal Advice

\begin{tabular}{|c|c|}
\hline $\begin{array}{c}\text { Working } \\
\text { Hypothesis } \\
4\end{array}$ & If banks introduce robo-advisory services, then the personal service will \\
become obsolete.
\end{tabular}

Referring to the working hypothesis 4, robo-advice is indeed capable of replacing personal service to a certain degree. Standardized services do not require personal support (Expert 10). Robo-advisory provides efficient and legally compliant processes to meet average customer needs (Expert 9). But as the experts and findings already mentioned, the qualitative element is still a demanded service in the context of complex businesses with HNWI.

\section{Discussion}

The necessity of traditional banks to implement a robo-advice solution is confirmed by all interview experts. Against the background of the digital transformation in the banking industry, robo-advisory constitutes a natural "evolution" of the bank offering (Expert 13). In spite of existing service limitations, Phoon and Koh see a definite upcoming disruption in traditional wealth management (Phoon \& Koh, 2017). The future lies in hybrid wealth management business models. German bank clients are demanding general online and digital financial solutions. Therefore, product adjustments have to take place in order to meet the market demand. Uhl and Rohner even consider cooperations and acquisitions as opportunities to 
introduce robo-advice in traditional wealth management and bring it to the next level (Uhl \& Rohner, 2018).

Traditional banks such as Commerzbank or Quirin Privatbank have an essential advantage over FinTechs. A young company needs to build new IT infrastructures and gain knowledge in the challenging fields of bank regulation and its legal requirements. The recruitment of adequate personnel is associated therewith. In contrast, traditional banks can refer to a longstanding expertise and knowledge foundation in this important fields. Besides, they can refer to existing customer relationships. The findings of Cocca emphasize the still existing appreciation of German customers towards human advice (Cocca, 2016). The introduction of roboadvice goes in hand with this beneficial fact. Whereas FinTechs have higher initial costs, banks can offer robo-advisory by taking advantage of existing infrastructures and personnel. The representative of the roboadvisor quirion sees his market dominance due to that fact (Expert 10).

"Other Stand-Alone-Robo-Advisor, as a real startup, have the additional costs. They need a new compliance, audit as well as legal department and that costs a lot of money."

(Expert 10)

The described potential competitive advantage goes along with the finding on the misleading price-performance-ratio. As long as robo-advisors hold on to their high pricings, banks have a good chance to position a fair counteroffer. Business synergies enable lower initial and running costs. Despite the state of market consolidation, new robo-advisors with a clear differentiation strategy will attract and scale (Expert 6).

Further recommendations can deal with the (1) introduction of a modular service offering, (2) integration of third-party banks through API interfaces and (3) utilization of big data and artifical intelligence.

The hypothesis testing, the elaboration on the central issue as well as the presented findings and recommendations underlie specific limitations regarding the scientific approach:

1. Limited number of interview experts $(n=14)$ and individual opinions of company representatives

2. Despite the objective literature-review, the content analysis with the coding system as well as the given interpretations of the author remain a subjective research element

3. Further research recommendation to implement larger sample for expert interviews with additional robo-advisors and traditional banks on market

\section{Conclusion}

The present qualitative study has the objective to examine the disruptive potential of robo-advisory on traditional wealth management providers in Germany. By 
interviewing top-ranking experts from the financial industry, the obtained information represents a strategic management view in cross section.

Despite the fact, that robo-advisory still represents an insufficient service, all experts agree on the high relevance for future wealth management. According to Edwards, robo-advisory services generally offer added value and thus show high business potential (Edwards, 2018). Traditional bank companies are advised to introduce roboadvice as additional sales channel to meet changing customer demands.

This work constitutes a starting point for further quantitative research approaches on the German investment market. One hypothesis could be, that German retail bank customers prefer financial institutions with a digital investment offering over traditional solutions without any digital advisory element. Another hypothesis could deal with the modularisation of robo-advisory offerings and the eligibility for both retail and HNWI clients. Both mentioned hypotheses could be investigated by conducting an extensive customer survey regarding the client needs in investment advisory.

The given central issue in this work is confirmed, that robo-advisory disrupts the investment business of banks by forcing adjustments in the service offering. Roboadvice is eligible for retail investors with standardized financial demands but does not yet fulfil sophisticated requirements of HNWIs. Hence, it substantiates the scalingstrategy-paradox, which prevents market growth for scale effects and profitability. All bank interview experts agree on the necessity of introducing roboadvisory as an additional service, but many of them still have not started the preparations for a possible market launch.

All in all, robo-advisory still represents a novelty on the German market and requires more financial research and business attention. In addition, regulation will concurrently develop to keep up with investor protection (Baker \& Dellaert, 2018, Ji, 2017). According to the literature-review and conducted expert interviews, the robobusinessmodel substantiates a future segment in modern banking.

\section{References}

[1] Baker, T. and Dellaert, B. (2018). Regulating Robo Advice Across the Financial Services Industry, Iowa Law Review, vol. 103, pp. 713-750.

[2] Beyer, C. (2017). Evolution and Disruption in the Wealth Management Industry, The Journal of Wealth Management, vol. 19, pp. 8-13.

[3] CFA Institute (April 2016). Fintech Survey Report. CFA Institute. [Online]. pp. 122. Available: https://www.cfainstitute.org/en/research/surveyreports/fintechsurvey-report-april-2016

[4] Chen, H., Ju, N. and Miao, J. (2011). Dynamic Asset Allocation with Ambiguous Return Predictability, Review of Economic Dynamics, vol. 17, pp. 799-823.

[5] Clarfeld, R. (May 2017). Why Robo-Advisors Don't Worry Me. Forbes. [Online].

Available:

https://www.forbes.com/sites/robclarfeld/2017/05/05/whyroboadvisors-dont-worry-me/\#3378d3991e83 
[6] Cocca, T. (2016). Potential and Limitations of Virtual Advice in Wealth Management. Journal of Financial Transformation, vol. 44, pp. 45-57.

[7] Edwards, B. P. (2018). The Rise of Automated Investment Advice - Can RoboAdvisors Rescue the Retail Market?, Chicago-Kent Law Review, vol. 96, pp. 97112.

[8] Faber, M. (2018). A Quantitative Approach to Tactical Asset Allocation Revisited 10 Years Later, The Journal of Portfolio Management, vol. 44, pp. 156-167.

[9] Faloon, M and Scherer B. (2017). Individualization of Robo-Advice, The Journal of Wealth Management, vol. 20, pp. 30-36.

[10] Fein, M. L. (June 2015). Robo-advisors: A Closer Look. SSRN. [Online]. pp. 1-33. Available: https://ssrn.com/abstract $=2658701$

[11] Fey, G. and Hohlmeier, M. (February 2018). Aktionärszahlen des Deutschen Aktieninstituts 2017. Deutsches Aktieninstitut. [Online]. pp. 1-12. Available: https://www.dai.de/de/das-bieten-wir/studien-und-statistiken/studien.html

[12] Freiberger, H. (February 2018). Kampf um Marktanteile. Sueddeutsche Zeitung. [Online]. Available: https://www.sueddeutsche.de/wirtschaft/roboadvisors-kampf-um-marktanteile$\underline{1.3873679}$

[13] Huxley, S. and Kim, J. Y. (December 2016). The Short-Term Nature of Robo Portfolios. Advisor Perspectives. [Online]. Available: https://www.advisorperspectives.com/articles/2016/09/12/the-short-term-natureofrobo-portfolios

[14] Jung, D., Dorner, V., Weinhardt, C. and Pusmaz, H. (2017). Designing a roboadvisor for risk-averse, low-budget consumers, Electronic Markets - The International Journal on Networked Business, p. 10.

[15] Khentov, B., Rosenbloom, S. and Conlon, T. (2016). Tastes Great, Less Conflict: How the Fiduciary Rule's "BIC Lite" Provision Will Accelerate Separation between Emerging Robo-Advice Platforms and Incumbents, Journal of Pension Benefits, vol. 24, pp. 43-48.

[16] Krahnhof, P. and Zureck, A. (2018). Konsequenzen aus Digitalisierung und Konsolidierung für kleinere Institute, Zeitschrift Für Das Gesamte Kreditwesen, vol. 18, pp. 16-20.

[17] Mayring, P. (2002). Einführung in die qualitative Sozialforschung. Eine Anleitung zu qualitativem Denken, 5th ed. Weinheim, Weinheim: Beltz-Verlag

[18] Meinert, M. C. (2017). Of Investments and Algorithms - Banks look to roboadvisers to meet changing customer needs, ABA Banking Journal, vol. 109, pp. 30-32.

[19] Phoon, K. and Koh, F. (2018). Robo-Advisors and Wealth Management, The Journal of Alternative Investments, vol. 20, pp. 79-94. 
[20] Singh, I. and Kaur, N. (2017). Wealth Management through Robo-Advisory, International Journal of Research - Granthaalayah, vol. 5, pp. 33-43

[21] Stiftung Warentest (July 2018). Robo-Advisors im Test: Was die automatisierte Vermögensverwaltung taugt. Stiftung Warentest. [Online]. pp. 1823. Available: https://www.test.de/Robo-advisor-Was'-dieautomatisierteVermoegensverwaltung-taugt-5107535-0/

[22] Tertilt, M. and Scholz, P. (2018). To advice, or not to advice - how robo advisors evaluate the risk preferences of private investors, The Journal of Wealth Management, vol. 21, pp. 70-84.

[23] Uhl, M. W. and Rohner, P. (2018). Robo-Advisors versus Traditional Investment Advisors: An Unequal Game, The Journal of Wealth Management, vol. 21, pp. 44-50.

[24] van Raaij, W. F. (2017). Explaining customer experience of digital financial advice, Economics World, vol. 5, pp. 69-84

[25] van Thiel, D. and van Raaij, W. F. (2017). Targeting the robo-advice customer: the development of a psychographic segmentation model for financial advice robots, Journal of Financial Transformation, vol. 46, pp. 88-101

[26] Zureck, A., Reiter, J. \& Svoboda, M. (2018). Cross-Generational Investment Behavior and the Impact on Personal Finance, Journal of International Business Research and Marketing, vol. 3(2), pp. 16-18

[27] Zureck, A. \& Jäger, T. (2018). Migration Background and its Impact on Personal Investments of in Germany Living People, International Journal of Innovation and Economic Development, vol. 4(3), pp. 7-11. 